\title{
Adsorption of O-Cresol in Landfill Leachate Using Activated Carbon
}

\author{
Shabiimam M. A. and Anil Kumar Dikshit, Member, IACSIT
}

\begin{abstract}
The adsorptive removal of o-cresol from dilute aqueous solutions was carried using commercial activated carbon. Batch mode studies were performed by varying parameters such as $\mathrm{pH}$, adsorbent dosage and time. It was found that adsorption with activated carbon can remove up to $95 \%$ of o-cresol from the wastewater within 10 minutes. The optimum process variables of this adsorption of 0 -cresol were found as $\mathrm{pH} 8$ and adsorption dosage $5 \mathrm{~g} / \mathrm{L}$. The adsorption followed Langmuir Isotherm.
\end{abstract}

Index Terms-Activated carbon, adsorption, freundlich and langmuir isotherm, o-Cresol.

\section{INTRODUCTION}

o-cresol is mostly used in the production of pesticides, epoxy resins, dyes, pharmaceuticals, disinfectants and cleaning agents. The worldwide production of o-cresol is approximately 37000-38000 tons/annum [1]. Approximately $60 \%$ of o-cresol is derived from coal tar and crude oil using classical techniques such as distillation, stripping, liquid-liquid extraction. Remaining amount is obtained synthetically by alkylation of phenol with methanol, either in the vapour or liquid phase. Cresols are found as contaminants in landfill leachate (Table I) and these are largely released to the groundwater via landfills [2]. Anaerobic sewage sludge experiments in anaerobic groundwater samples showed that cresol isomers display the pattern of degradation as p-cresol $>$ m-cresol $>$ o-cresol, where $\mathrm{p}$-cresol is the most readily biodegradable of the three isomers [2]. Horowitz et al. [3] reported that in anoxic sediments, $\mathrm{m}$ - and $\mathrm{p}$-cresol isomers showed the maximum degradation, while o-cresol resisted degradation. Kurata et al. [4] investigated occurrence of phenolic compounds in leachates from 38 Municipal Solid Waste landfills in Japan and found that most of the landfill leachates contained 3.7 $\mu \mathrm{g} / \mathrm{L}$ of o-cresol. Most health exposures of o-cresol observed in people include irritation and burning of skin, eyes, mouth, and throat, abdominal pain and vomiting, heart damage, anemia, liver and kidney damage facial paralysis, coma, and death [5].

Table I shows the typical characteristics of landfill leachate as reported in literature [6]. The characteristics of MSW landfill leachate vary with time and from site to site because dependence on type of wastes disposed, rainfall, age of the landfill and design of the landfill etc [7].

Manuscript received February 6, 2012; revised March 18, 2012.

Shabiimam M. A and Anil Kumar Dikshit are with the Centre for Environmental Science and Engineering, Indian Institute of Technology Bombay, Mumbai, India (e-mail: shabiimam@iitb.ac.in; dikshit@iitb.ac.in).
TABLE I: TYPICAL CHARACTERISTICS OF LANDFILL LEACHATE

\begin{tabular}{lcl}
\hline \hline Parameter & Unit & Range \\
\hline Cresols & $\mu \mathrm{g} / \mathrm{L}$ & $1-2100$ \\
Phenols & $\mu \mathrm{g} / \mathrm{L}$ & $0.6-1200$ \\
Bisphenol A & $\mu \mathrm{g} / \mathrm{L}$ & $200-240$ \\
$\mathrm{pH}$ & -- & $4.5-9$ \\
$\mathrm{COD}$ & $\mathrm{mg} / \mathrm{L}$ & $140-152000$ \\
$\mathrm{BOD}$ & $\mathrm{mg} / \mathrm{L}$ & $20-57000$ \\
TOC & $\mathrm{mg} / \mathrm{L}$ & $30-29000$ \\
Organic Nitrogen & $\mathrm{mg} / \mathrm{L}$ & $14-2500$ \\
BOD $_{5} / \mathrm{COD}$ & -- & $0.02-0.8$ \\
\hline \hline
\end{tabular}

Source: [6]

Table II shows typical COD removal efficiencies of various physical/chemical treatments.

\begin{tabular}{lllll}
\multicolumn{5}{c}{ TABLE II: Phyico Chemical TREATMENT OF LANDFILl LEACHATE } \\
\hline \hline $\begin{array}{l}\text { Coagulant } \\
\text { Used }\end{array}$ & $\begin{array}{l}\text { COD } \\
\text { Removal (\%) }\end{array}$ & $\begin{array}{l}\text { Optimum } \\
\mathrm{pH}\end{array}$ & $\begin{array}{l}\text { Optimum } \\
\text { Dose }(\mathrm{g} / \mathrm{L})\end{array}$ & References \\
\hline Alum & 54 & 6 & 15 & {$[8]$} \\
$\begin{array}{l}\text { Calcium } \\
\text { Hydroxide }\end{array}$ & 69 & 8 & 25 & {$[8]$} \\
$\begin{array}{l}\text { Ferrous } \\
\text { Sulphate }\end{array}$ & 62 & 10 & 20 & {$[9]$} \\
Potash Alum & 69 & 6 & 10 & {$[9]$} \\
\hline \hline
\end{tabular}

Shabiimam and Dikshit [8] investigated the removal of organic load (COD) using coagulation from MSW leachate. Alum and lime (calcium hydroxide) were used as coagulants and a maximum of $69 \%$ organic load removal was achieved using lime. In another study, ferrous sulphate and potash alum used as coagulants and maximum removal of $69 \%$ COD was reported using the dose of $10 \mathrm{~g} / \mathrm{L}$ potash alum at optimum $\mathrm{pH} 6$ [9].

Adsorption is also one of physical treatment processes and it is a surface treatment in which specific solutes in liquid are attracted to the surface of solid adsorbent. Activated carbon is widely used adsorbent and it gives high COD reduction efficiency. 91\% COD removal was reported in activated carbon column performance studies on biologically pretreated leachate [10]. Rodriguez et al. [11] investigated the removal of non-biodegradable matter from landfill leachate by adsorption using activated carbon and they reported 59\% COD removal.

\section{MATERIALS AND METHODS}

\section{A. Chemicals}

All chemicals used in the present study were of analytical grade (A.R.), purchased from Merck chemicals, Mumbai, India. Powdered activated carbon (having methylene blue 
rated adsorption capacity as greater than $180 \mathrm{mg} / \mathrm{g}$ ) was also procured from Merck Chemicals and was used as an adsorbent in this study.

\section{B. Analytical Methods}

$\mathrm{pH}$ of the wastewater was measured by a digital $\mathrm{pH}$ meter (Polmon, LP-1395, India). COD was determined by the standard closed reflux method using a COD reactor (Hach, DRB200 COD reactor, USA) [12]. TOC was measured using a TOC analyzer (Shimadzu, TOC-V $\mathrm{V}_{\mathrm{CSH}}$, Japan).

\section{Estimation of o-Cresol}

o-Cresol was estimated using spectro-photometric method as proposed by APHA [12]. o-cresol was rapidly condensed with 4-Aminoantipyridine followed by its oxidation with potassium ferricyanide at $\mathrm{pH} 7.9$ to yield red coloured compound. The absorbance was measured at $510 \mathrm{~nm}$ using UV-Visible spectrophotometer (Thermoelectron Corporation, GENESYS 20, USA).

\section{D. $p H$ Study}

The optimum $\mathrm{pH}$ for the process was determined from the data obtained from experiments carried out at varying initial $\mathrm{pH}(2,4,6,8,10$ and 12) and all subsequent experiments were carried out at this $\mathrm{pH}$.

\section{E. Dosage Study}

Adsorbent dosage was optimized by performing the experiments at varying adsorbent dosage $(2,3,4,5,6$ and 7 $\mathrm{g} / \mathrm{L})$ at optimum $\mathrm{pH}$. Aliquots of the sample were collected at specified time intervals (10, 20, 30, $40 \mathrm{~min})$ and analyzed by TOC and o-cresol by spectro-photometric method. The data obtained were used to plot isotherms to describe the adsorption process.

\section{F. Batch Adsorption Study}

o-cresol (500 mg/L, TOC $417 \mathrm{mg} / \mathrm{L})$ was used as the model compound for adsorption studies. All the adsorption experiments were done in $100 \mathrm{~mL}$ glass-stoppered bottles containing pre-determined amount of activated carbon as adsorbent with $50 \mathrm{~mL}$ of synthetic wastewater. The flasks were labeled and kept in an orbital shaker (Trishul equipments, Thane) at a speed $120 \mathrm{rpm}$ for 60 minutes. Batch experiments were carried out to evaluate the effect of the following parameters on the removal of o-cresol from the wastewater: $\mathrm{pH}$, adsorbent dose and time. To evaluate the efficiency of adsorption, o-cresol and TOC of the wastewater before and after the treatment were determined. All the runs were carried out in duplicate to confirm the results.

\section{RESUlTS AND Discussion}

In this study, adsorption of a specific organic compound, o-cresol, was studied, which is a normal component of landfill leachate.

\section{A. Characteristics of Landfill leachate}

The landfill leachate was collected from an old MSW dumping ground at Mumbai, India and its physical and chemical characteristics were determined and are presented in Table III.
TABLE III: CHARACTERISTICS OF LANDFILL LEACHATE FROM LANDFILL IN MUMBAI

\begin{tabular}{|c|c|c|}
\hline Parameter & Unit & Value \\
\hline $\mathrm{pH}^{*}$ & -- & 7.8 \\
\hline Colour* & Dark brown & Dark brown \\
\hline COD & $\mathrm{mg} / \mathrm{L}$ & 2451 \\
\hline TOC & $\mathrm{mg} / \mathrm{L}$ & 1002 \\
\hline $\mathrm{BOD}_{5}$ & $\mathrm{mg} / \mathrm{L}$ & 645 \\
\hline TS & $\mathrm{mg} / \mathrm{L}$ & 8985 \\
\hline TDS & $\mathrm{mg} / \mathrm{L}$ & 7251 \\
\hline TSS & $\mathrm{mg} / \mathrm{L}$ & 1734 \\
\hline $\mathrm{Na}$ & $\mathrm{mg} / \mathrm{L}$ & 17740 \\
\hline K & $\mathrm{mg} / \mathrm{L}$ & 583.2 \\
\hline $\mathrm{Mg}$ & $\mathrm{mg} / \mathrm{L}$ & 172.7 \\
\hline $\mathrm{Ca}$ & $\mathrm{mg} / \mathrm{L}$ & 99.56 \\
\hline B & $\mathrm{mg} / \mathrm{L}$ & 54.24 \\
\hline $\mathrm{Ba}$ & $\mathrm{mg} / \mathrm{L}$ & 42.41 \\
\hline $\mathrm{Si}$ & $\mathrm{mg} / \mathrm{L}$ & 25.56 \\
\hline $\mathrm{Fe}$ & $\mathrm{mg} / \mathrm{L}$ & 3.820 \\
\hline Co & $\mathrm{mg} / \mathrm{L}$ & 4.744 \\
\hline As & $\mathrm{mg} / \mathrm{L}$ & 0.932 \\
\hline $\mathrm{Se}$ & $\mathrm{mg} / \mathrm{L}$ & 1.226 \\
\hline $\mathrm{Cr}$ & $\mathrm{mg} / \mathrm{L}$ & 0.299 \\
\hline $\mathrm{Cu}$ & $\mathrm{mg} / \mathrm{L}$ & 0.167 \\
\hline $\mathrm{Li}$ & $\mathrm{mg} / \mathrm{L}$ & 0.265 \\
\hline $\mathrm{Mn}$ & $\mathrm{mg} / \mathrm{L}$ & 0.098 \\
\hline $\mathrm{Ni}$ & $\mathrm{mg} / \mathrm{L}$ & 0.633 \\
\hline $\mathrm{Pb}$ & $\mathrm{mg} / \mathrm{L}$ & 0.313 \\
\hline $\mathrm{Zn}$ & $\mathrm{mg} / \mathrm{L}$ & 0.231 \\
\hline $\mathrm{Al}$ & $\mathrm{mg} / \mathrm{L}$ & 0.109 \\
\hline $\mathrm{Cd}$ & $\mathrm{mg} / \mathrm{L}$ & 0.026 \\
\hline
\end{tabular}

The leachate sample had total solids (8985 mg/L) and dissolved solids $(7251 \mathrm{mg} / \mathrm{L})$. It is reported that young landfills contain large amounts of biodegradable organic matter causing a rapid anaerobic fermentation, resulting in the generation of volatile fatty acids (VFA) as the main fermentation products [13]. As a landfill matures, the methanogenic phase occurs. Methanogenic microorganisms develop in the waste, and the VFA are converted to biogas $\left(\mathrm{CH}_{4}, \mathrm{CO}_{2}\right)$. The organic fraction in the leachate becomes dominated by refractory (non-biodegradable) compounds such as humic substances. The ratio of $\mathrm{BOD}_{5} / \mathrm{COD}$ (which generally varies from 0.04 to 0.70 ) decreases rapidly with the aging of the landfills [6]. For a medium aged landfill the COD values range from 1180 to $9500 \mathrm{mg} / \mathrm{L}$ whereas for a old landfill, the COD may range between $100-10,000 \mathrm{mg} / \mathrm{L}$ [14]. The $\mathrm{BOD}_{5}$ values for medium and old landfill range from $330-1400 \mathrm{mg} / \mathrm{L}$ and 3-800 $\mathrm{mg} / \mathrm{L}$ respectively [14]. The COD and $\mathrm{BOD}_{5}$ values of the leachate shown in Table III indicate that the landfill is old. Some trace amounts of toxic metals like $\mathrm{Pb}, \mathrm{Co}$, and $\mathrm{Li}$ were also present in the landfill leachate.

\section{B. Characteristics of o-Cresol}

The characteristics of o-cresol are shown in Table IV. Initial $\mathrm{pH}$ was 6.8 and $417 \mathrm{mg} / \mathrm{L}$ of TOC.

\section{Effect of $\mathrm{pH}$ on the Adsorption of o-Cresol}

Results obtained from the adsorption of o-cresol at varying initial $\mathrm{pH}$ values are presented in Fig. 1a. Powdered activated carbon dose was kept $2 \mathrm{~g} / \mathrm{L}$ in all the runs. It can be seen that TOC removal was maximum at $\mathrm{pH} 8$ and showed $65.3 \%$ reduction from the initial value. 
TABLE IV: CHARACTERISTICS OF O-CRESOL

\begin{tabular}{lll}
\hline \hline Parameter & Unit & Value \\
\hline $\mathrm{pH}$ & -- & 6.8 \\
$\mathrm{COD}$ & $\mathrm{mg} / \mathrm{L}$ & 1655 \\
$\mathrm{TOC}$ & $\mathrm{mg} / \mathrm{L}$ & 417 \\
Melting- Point & ${ }^{\circ} \mathrm{C}$ & 31 \\
Boiling-point & ${ }^{\circ} \mathrm{C}$ & 191 \\
Density & $\mathrm{kg} / \mathrm{m}^{3}$ & 1046 \\
\hline \hline
\end{tabular}

Hence, all subsequent experiments were carried out at $\mathrm{pH}$ 8. Similar trend was also obtained for the concentration of $\mathrm{o}$-cresol at different $\mathrm{pH}$ values (Fig. 1b).

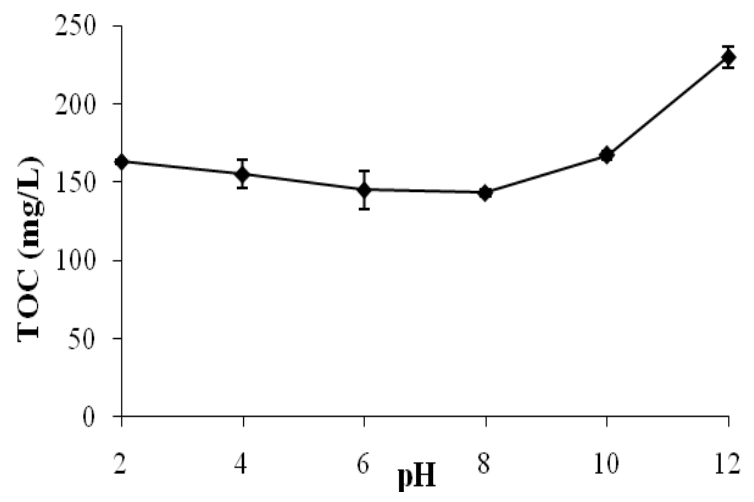

(a)

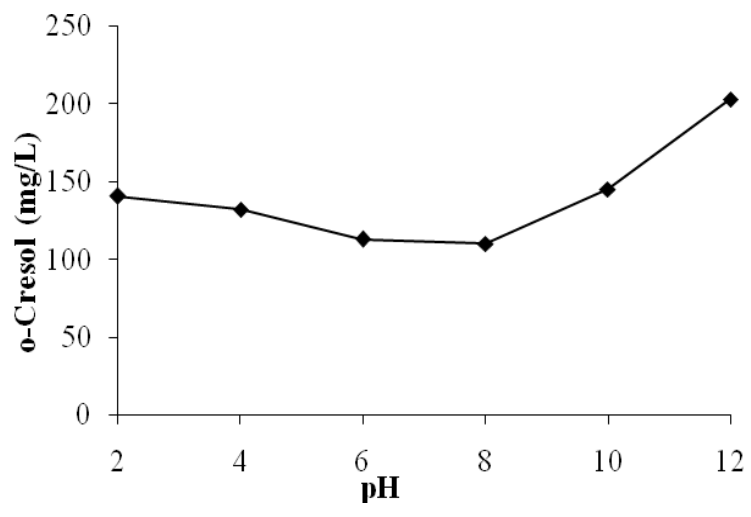

(b)

Fig. 1. Effect of $\mathrm{pH}$ on the adsorption of o-cresol. Experimental conditions: activated carbon used $=2 \mathrm{~g} / \mathrm{L}$; initial concentration of o-cresol $=500 \mathrm{mg} / \mathrm{L}$, initial TOC $=417 \mathrm{mg} / \mathrm{L}$.

\section{Effect of Adsorbent Dose}

To observe the effect of adsorbent dose, the runs were conducted at different doses $(2,3,4,5,6$ and $7 \mathrm{~g} / \mathrm{L})$. From Fig. 2, it can be seen that TOC decreased remarkably when the adsorbent dosage was increased from 2 to $3 \mathrm{~g} / \mathrm{L}$.

Beyond this adsorbent dose, TOC and substrate concentration continued to decrease. But it was found that any addition of adsorbent in the excess of $5 \mathrm{~g} / \mathrm{L}$ did not exhibit applicable decrease ( $<50 \%$ from the previous value) o-Cresol reduction always occurred in the same meaner as the TOC was due to o-cresol only. Hence, all subsequent experiments were carried out using $5 \mathrm{~g} / \mathrm{L}$ dose.

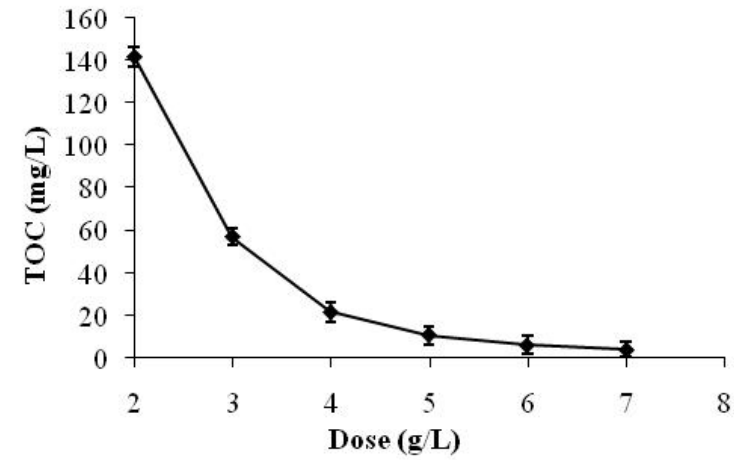

(a)

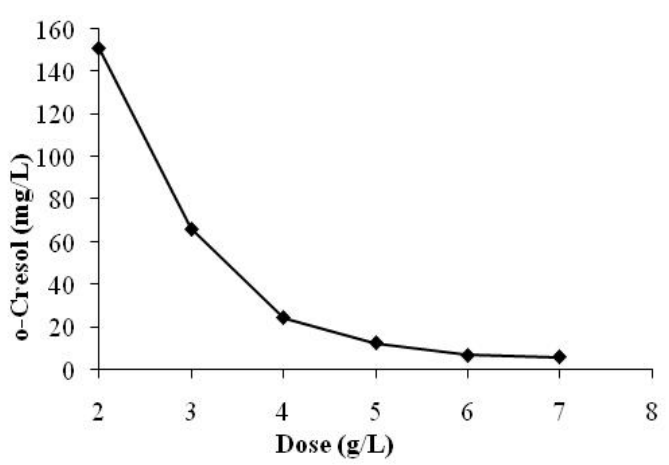

(b)

Fig. 2. Effect of adsorbent dose on the adsorption of o-cresol. Experimental conditions: experimental $\mathrm{pH}=8$; initial concentration of o-cresol $=500$ $\mathrm{mg} / \mathrm{L}$; initial $\mathrm{TOC}=417 \mathrm{mg} / \mathrm{L}$.

\section{E. Effect of $\mathrm{pH}$ on the Adsorption of o-Cresol}

The effect of reaction time on the overall o-cresol removed was studied by withdrawing samples at an interval of 10 minutes. The total duration of the run was 40 minutes. The adsorbent was taken $5 \mathrm{~g} / \mathrm{L}$ and the solution $\mathrm{pH}$ was kept at 8 . The results are plotted in Fig. 3. It can be seen that $95 \%$ removal of TOC occurred in 40 minutes. However, most of the removal was achieved within 10 minutes.

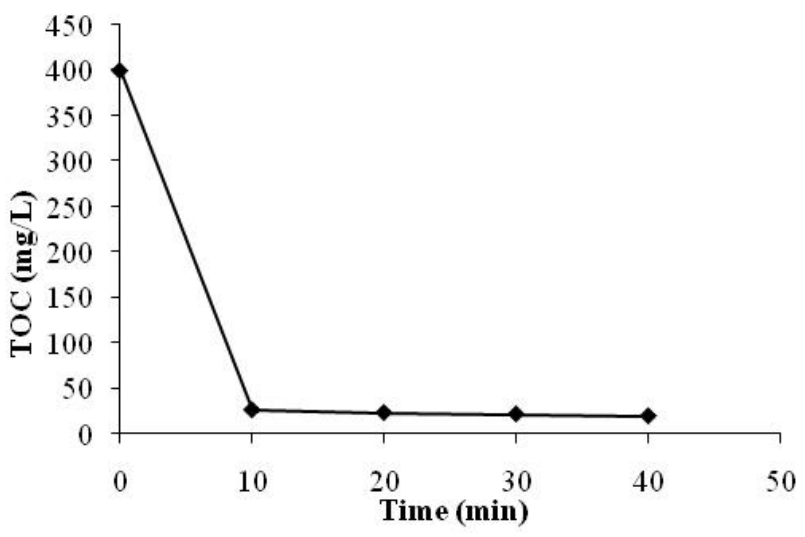

Fig. 3. Effect of time on the adsorption of o-cresol. Experimental conditions: activated carbon used $=5 \mathrm{~g} / \mathrm{L} ; \mathrm{pH}$ maintained $=8$; initial concentration of o-cresol $=500 \mathrm{mg} / \mathrm{L}$.

Figure 4 shows the adsorption of o-cresol on activated carbon as a function of equilibrium concentration. 


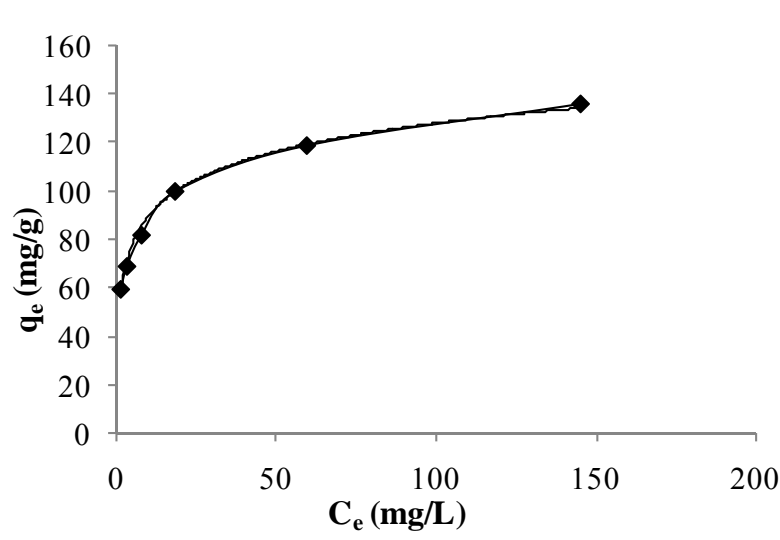

Fig. 4. Adsorption of o-cresol on activated carbon.

\section{F. Langmuir Isotherm}

The results obtained for the experimental studies were fitted for Langmuir isotherm [2, 15] described by the following equation:

$$
\mathrm{q}_{\mathrm{e}}=\mathrm{K}_{\mathrm{L}} \mathrm{C}_{\mathrm{e}} /\left(1+\mathrm{bC}_{\mathrm{e}}\right)=\mathrm{q}_{\mathrm{m}} \mathrm{bC}_{\mathrm{e}} /\left(1+\mathrm{bC}_{\mathrm{e}}\right)
$$

where $\mathrm{q}_{\mathrm{e}}$ is the adsorption capacity $(\mathrm{mg} / \mathrm{g}), \mathrm{C}_{\mathrm{e}}$ is equilibrium concentration of adsorbate $(\mathrm{mg} / \mathrm{L}), \mathrm{K}_{\mathrm{L}}$ and $\mathrm{b}$ are Langmuir constants, and $\mathrm{q}_{\mathrm{m}}$ is the Langmuir monolayer adsorption capacity.

\section{G. Freundlich Isotherm}

The results obtained for the experimental studies were fitted also fitted for Freundlich isotherm equation $[1,16]$ :

$$
\mathrm{q}_{\mathrm{e}}=\mathrm{K}_{\mathrm{F}} \mathrm{C}_{\mathrm{e}}{ }^{(1 / \mathrm{n})}
$$

where $\mathrm{q}_{\mathrm{e}}$ is adsorption capacity $(\mathrm{mg} / \mathrm{g}), \mathrm{C}_{\mathrm{e}}$ is equilibrium concentration of adsorbate $(\mathrm{mg} / \mathrm{L})$, and $\mathrm{K}_{\mathrm{F}}$ and $\mathrm{n}$ are Freundlich constants.

The obtained equilibrium adsorption data shown in Fig. 4 were fitted to Langmuir and Freundlich isotherms. Fig. 5 shows the Langmuir and Freundlich Isotherm plots while the parameters for both the models are presented in Table V.

TABLE V: ISOTHERM PARAMETERS FOR THE ADSORPTION OF O-CRESOL ON ACTIVATED CARBON

\begin{tabular}{lllll}
\hline \hline Model & $\mathrm{K}_{\mathrm{L}}$ & $\mathrm{Q}_{\max }$ & $\mathrm{b}$ & $\mathrm{R}^{2}$ \\
\hline Langmuir & 142 & 27.78 & 5.142 & 0.997 \\
Model & $\mathrm{K}_{\mathrm{f}}$ & $1 / \mathrm{n}$ & $\mathrm{n}$ & $\mathrm{R}^{2}$ \\
Freundlich & 56.24 & 0.1819 & 5.497 & 0.995 \\
\hline \hline
\end{tabular}

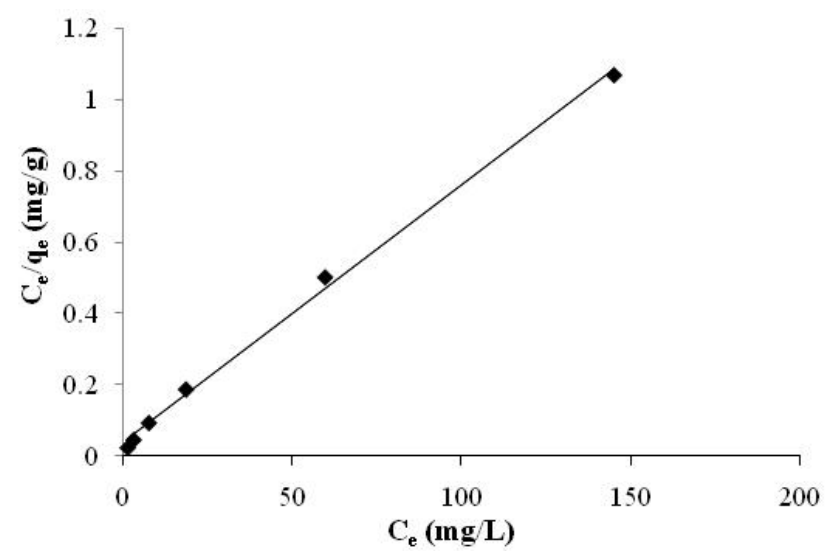

(a)

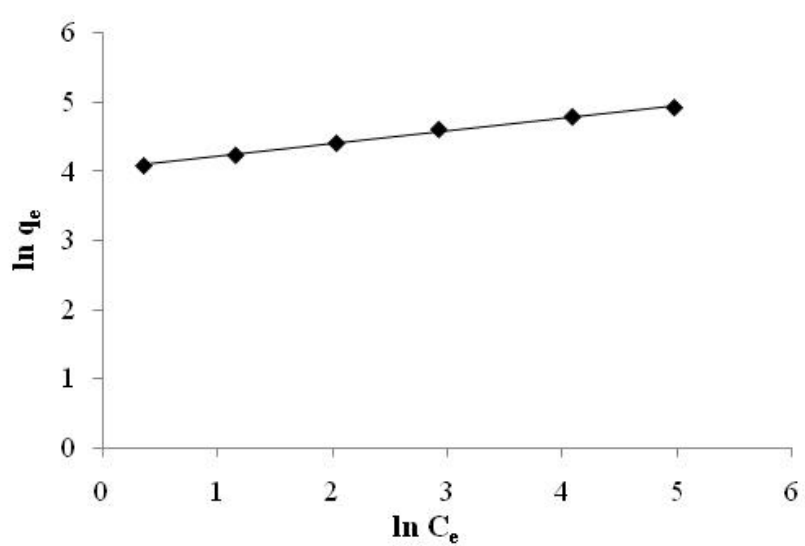

(b)

Fig. 5. Langmuir (a) and Freundlich (b) isotherms for adsorption of o-cresol on activated carbon.

\section{CONCLUSION}

Optimal leachate treatment is necessary in order to reduce its negative impact on the environment. However, it is difficult to formulate the leachate treatment, in general, as the leachate composition varies with time and with site. Also, leachate characteristics depend on the age of landfill, waste characteristics, and climatic conditions of the area.

The present study demonstrated that the commercial activated carbon can remove up to $95 \%$ of o-cresol from the wastewater within 10 minutes by adsorption technique. The results were described by Langmuir Isotherm.

The optimum process variables of the adsorption of $\mathrm{o}$-cresol onto activated carbon were found as $\mathrm{pH}$ of 8 at an adsorbent dosage of $5 \mathrm{~g} / \mathrm{L}$.

\section{ACKNOWLEDGMENT}

The authors thank the management and staff of the Solid Waste Division, Municipal Corporation of Greater Mumbai, Mumbai, India for providing the landfill leachate used in the research work.

\section{REFERENCES}

[1] A. D. Vasu. "Removal of phenol and o-cresol by adsorption onto activated carbon," E-Journal of Chemistry, vol. 5(2), pp. 224-232, 2008.

[2] ATSDR. (September 2008). Toxicological Profile for Cresols. Available: http://www.atsdr.cdc.gov/toxprofiles/index.asp

[3] A. Horowitz, D. R. Shelton, and C. P. Cornell, "Anaerobic degradation of aromatic compounds in sediments and digested sludge," Developments in Industrial Microbiology, vol. 23, pp. 435-444, 1982.

[4] Y. Kurata, Y. Ono, and Y. Ono, "Occurrence of phenols in leachates from municipal solid waste landfill sites in Japan," Journal of Material Cycles and Waste Management vol. 10(2), pp. 144-152, 2008.

[5] H. I. Maarof, B. H. Hameed, and A. L. Ahmad, "Adsorption Isotherm of o-cresol from Aqueous Solution by Granular Activated Carbon". Proc. International Conference on Chemical and Bioprocess Engineering. Universiti Malaysia Sabah, 2003, pp. 111-114.

[6] P. Kjeldsen, M. Barlaz, A. Rooker, A. Baun, A. Ledin, and T. H. Christensen, "Present and Long-Term Composition of MSW Landfill Leachate: A Review," Critical Reviews in Environmental Science and Technology, vol. 32(4), pp. 297-336, 2002.

[7] J. M. Lema, R. Mendez, and R. Blazquez, "Characteristics of landfill leachates and alternatives for their treatment: a review," Water Air Soil Pollution, vol 40, pp. 223-250, 1988.

[8] M. A. Shabiimam, and A.K. Dikshit, "Treatment of Landfill Leachate using Coagulation," in proc. 2011 International Conference on 
Environmental Science and Technology (ICEST 2011), Singapore, IPCBEE, Vol.6: 119-122, Feb 2011.

[9] M. A. Shabiimam and A. K. Dikshit, "Municipal Landfill Leachate Treatment using Coagulation Process," Presented at International Conference on Emerging Green Technologies (ICEGT 2011), Periyar Maniammai University, Thanjavur, July 27-30, 2011.

[10] B. Morawe, D. S. Ramteke, and A. Vogelpohl, "Activated Carbon Column Performance Studies of Biologically Treated Landfill Leachate," Chemical Engineering Process, vol. 34, pp. 299-303, 1995

[11] J. Rodríguez, L. Castrillon L, E, Maranon, H. Sastre, and Fernández E, "Removal of non-biodegradable organic matter from landfill leachates by adsorption," Water research, vol. 38(14-15), 3297-3303, 2004

[12] Standard Methods for the Examination of Water and Wastewater, American Public Health Association (APHA). 21st ed., Washington, DC, 2005.

[13] U. Welander, U. Henrysson, and T. Welander, "Biological nitrogen removal from municipal landfill leachate in a pilot scale suspended carrier biofilm process," Water Research, vol. 32(5), pp. 1564-1570, 1998

[14] S. Renou, J. G. Givaudan, S. Poulain, F. Dirassouyan, and P. Moulin, "Landfill leachate treatment: review and opportunity," Journal of Hazardous Materials," vol 150(3), pp. 468-493, 2008.

[15] S. Juang, F. C. Wu, and R. L. Tseng, "Adsorption isotherms of phenolic compounds from aqueous solutions onto activated carbon fibers," Journal of Chemical \& Engineering Data, vol 41 (3), 487-492, 1996

[16] Y. Foo and B. H. Hameed. "Insights into the modeling of adsorption isotherm systems," Chemical Engineering Journal, vol. 156 (1): pp $2-10,2010$

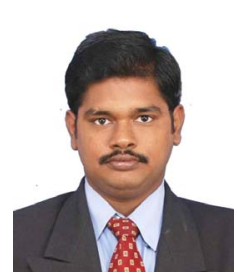

Shabiimam M. A. has B.Tech. in Chemical Engineering from Anna University, Tamilnadu, India in 2006 and completed Post graduation (M.Tech) in Industrial Pollution Control from National Institute of Technology Karnataka, Surthkal, India in 2009.

Presently he is working as a Research Scholar at the Centre for Environmental Science and Engineering at Indian Institute of Technology Bombay, India.

His main research interests are Solid Waste Management, Municipal
Landfill Leachate Treatment. Water and Wastewater Treatment Options, Environmental System Modeling and Advance oxidation processes. He has 10 publications to his credit.

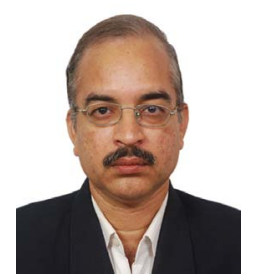

Anil Kumar Dikshit did graduation in Civil Engineering from H.B.T.I, Kanpur, 1985; M.Tech (Civil Eng.) from Indian Institute of Technology, Kanpur, 1987 and PhD (Civil and Environ Eng.), Cornell University, USA, 1994. About 20 years of experience in Teaching and Research at IIT Kanpur, Cornell University, IIT Kharagpur and IIT Bombay. He is Honorary Professor at School of Civil Engineering, Survey and Construction, University of KwaZulu-Natal, Durban, South Africa and also Visiting Professor, School of Civil and Environmental Engineering, Nanyang Technological University, Singapore

The areas of his interest in teaching are environmental systems planning and management; environmental impact assessment; water supply and wastewater engineering; environmental engineering; and solid waste management while the areas of research interest include water and wastewater treatment; environmental modelling and optimization; and GIS applications to water and environment related problems.

$\mathrm{He}$ is honorary professor of School of Civil Engineering, Survey and Construction, University of KwaZulu-Natal, Durban, South Africa. Also he is visiting professor of School of Civil and Environmental Engineering, Nanyang Technological University, Singapore.

He has guided 31 masters' and 8 doctoral scholars while 9 research scholars are working on their Ph.Ds. He has also worked on 30 national and international research and consultancy projects. $\mathrm{He}$ is having research collaboration with German, French, US, Singapore and South Africa Universities and Institutions. Organised 9 training courses and 9 conferences. The results of academic research work has provided one patent, three book, 7 chapters in edited books, 91 publications in international and national journals, 98 in international and national conferences while many more papers are being reviewed. In addition, academic versions of a number of environmental modeling and simulation models, and a number of GIS applications on environmental management problems have been developed under his guidance. He is associate editor, reviewer or editorial board member for many environmental journals. 